\title{
Video Article \\ Using a Pan-Viral Microarray Assay (Virochip) to Screen Clinical Samples for Viral Pathogens
}

\author{
Eunice C. Chen ${ }^{1}$, Steve A. Miller ${ }^{1}$, Joseph L. DeRisi ${ }^{1,2}$, Charles Y. Chiu ${ }^{1,2}$ \\ ${ }^{1}$ Department of Laboratory Medicine, University of California, San Francisco \\ ${ }^{2}$ Division of Infectious Diseases, University of California, San Francisco \\ Correspondence to: Charles Y. Chiu at charles.chiu@ucsf.edu \\ URL: https://www.jove.com/video/2536 \\ DOI: doi:10.3791/2536
}

Keywords: Immunology, Issue 50, virus, microarray, Virochip, viral detection, genomics, clinical diagnostics, viral discovery, metagenomics, novel pathogen discovery

Date Published: 4/27/2011

Citation: Chen, E.C., Miller, S.A., DeRisi, J.L., Chiu, C.Y. Using a Pan-Viral Microarray Assay (Virochip) to Screen Clinical Samples for Viral Pathogens. J. Vis. Exp. (50), e2536, doi:10.3791/2536 (2011).

\section{Abstract}

The diagnosis of viral causes of many infectious diseases is difficult due to the inherent sequence diversity of viruses as well as the ongoing emergence of novel viral pathogens, such as SARS coronavirus and 2009 pandemic H1N1 influenza virus, that are not detectable by traditional methods. To address these challenges, we have previously developed and validated a pan-viral microarray platform called the Virochip with the capacity to detect all known viruses as well as novel variants on the basis of conserved sequence homology ${ }^{1}$. Using the Virochip, we have identified the full spectrum of viruses associated with respiratory infections, including cases of unexplained critical illness in hospitalized patients, with a sensitivity equivalent to or superior to conventional clinical testing ${ }^{2-5}$. The Virochip has also been used to identify novel viruses, including the SARS coronavirus ${ }^{6,7}$, a novel rhinovirus clade ${ }^{5}$, XMRV (a retrovirus linked to prostate cancer) ${ }^{8}$, avian bornavirus (the cause of a wasting disease in parrots $)^{9}$, and a novel cardiovirus in children with respiratory and diarrheal illness ${ }^{10}$. The current version of the Virochip has been ported to an Agilent microarray platform and consists of $\sim 36,000$ probes derived from over $\sim 1,500$ viruses in GenBank as of December of 2009 . Here we demonstrate the steps involved in processing a Virochip assay from start to finish ( 24 hour turnaround time), including sample nucleic acid extraction, PCR amplification using random primers, fluorescent dye incorporation, and microarray hybridization, scanning, and analysis.

\section{Video Link}

The video component of this article can be found at https://www.jove.com/video/2536/

\section{Protocol}

The steps of the Virochip assay include (1) nucleic acid extraction from clinical samples, (2) reverse transcription of extracted RNA and $2^{\text {nd }}$ strand cDNA synthesis, (3) PCR amplification of randomly primed cDNA, (3) Cy3 fluorescent dye incorporation, (4) hybridization of labeled material to the Virochip microarray, and (5) scanning and analysis (Figure 1). The protocol shown below will demonstrate the use of the Virochip assay on a nasal swab sample from a child with an influenza-like illness.

\section{Primer Sequences}

Primer A 5'-GTTTCCCAGTCACGATA- $\left(\mathrm{N}_{9}\right)-3^{\prime}$

Primer B 5'-GTTTCCCAGTCACGATA-3'

\section{Nucleic Acid Extraction}

1. Nucleic acid extraction from clinical samples should be performed under Biosafety Level 2 (BSL-2) or higher conditions, as these samples are potentially infectious.

2. The nasal swab sample is transported in viral holding medium. Aliquot $200 \mu \mathrm{L}$ of the sample into a $1.5 \mathrm{~mL}$ Eppendorf microcentrifuge tube

3. Optional: pass sample through a $0.22 \mu \mathrm{m}$ filter (to purify for viral particles)

4. Optional: pretreat sample with DNAse (to degrade host genomic DNA and purify for protected, encapsidated viral nucleic acid) using the Turbo DNAse kit (Ambion) per the manufacturer's instructions

5. Extract the sample using the Zymo ZR Viral RNA Extraction Kit or Qiagen Ultrasens Virus Kit per the manufacturer's instructions.

\section{Reverse Transcription and $2^{\text {nd }}$-strand CDNA Synthesis ("Round $A "$ ")}

1. Add $1 \mathrm{uL} 40 \mathrm{pmol} / \mu \mathrm{L}$ Primer A to $4 \mathrm{uL}$ extracted RNA. Heat to $65^{\circ} \mathrm{C}$ for $5 \mathrm{~min}$ in a thermocycler (e.g. GeneAmp PCR System 9700 ) and then let cool at room temp $\times 5$ min. 
2. Add $5 \mu \mathrm{L}$ of a master mix consisting of $2 \mu \mathrm{L} 5 \mathrm{X}$ RT buffer, $1 \mu \mathrm{L} 12.5 \mathrm{mM}$ dNTP, $1 \mu \mathrm{L}$ water, $0.5 \mu \mathrm{L} 0.1 \mathrm{M}$ DTT, and $0.5 \mu \mathrm{L}$ SSIII RT (Invitrogen). Incubate at $42^{\circ} \mathrm{C} \times 60$ minutes.

3. In a programmable thermocycler, heat to $94^{\circ} \mathrm{C} \times 2 \mathrm{~min}$ (to abort the reverse transcriptase reaction), cool to $10^{\circ} \mathrm{C}$, pulse centrifuge, and then add $5 \mu \mathrm{L}$ Sequenase mix consisting of $1 \mu \mathrm{L} 5 \mathrm{X}$ Sequenase buffer, $3.8 \mu \mathrm{L}$ water, and $0.15 \mu \mathrm{L}$ Sequenase (USB Corporation). For $2^{\text {nd }}$ strand synthesis, ramp up from $10^{\circ} \mathrm{C}$ to $37^{\circ} \mathrm{C}$ over $8 \mathrm{~min}$, hold $8 \mathrm{~min}$, then heat to $94^{\circ} \mathrm{C} \times 2 \mathrm{~min}$ (to inactivate Sequenase) and cool to $10^{\circ} \mathrm{C} \mathrm{(hold).}$

4. Optional : Rd A sample cDNA can be stored at this point at $-20^{\circ} \mathrm{C}$.

\section{PCR Amplification of Randomly Primed CDNA ("Round B")}

1. Add $5 \mathrm{uL}$ of Rd A sample to $45 \mu \mathrm{L}$ of a master mix consisting of $5 \mu \mathrm{L} 10 \mathrm{X}$ PCR buffer, $1 \mu \mathrm{L} 12.5 \mathrm{mM}$ dNTP, $1 \mu \mathrm{L} 100 \mathrm{pmol} / \mu \mathrm{L}$ primer B, $1 \mu \mathrm{L}$ KlenTaq LA (Sigma), and $37 \mu \mathrm{L}$ water.

2. Run PCR protocol as follows: $94^{\circ} \mathrm{C}, 2 \mathrm{~min} \rightarrow\left(25\right.$ cycles of $\left.94^{\circ} \mathrm{C}, 30 \mathrm{~s} / 50^{\circ} \mathrm{C}, 45 \mathrm{~s} / 72^{\circ} \mathrm{C}, 1 \mathrm{~min}\right) \rightarrow 72^{\circ} \mathrm{C}, 5 \mathrm{~min} \rightarrow 10^{\circ} \mathrm{C}$ (hold)

3. Check the Rd B sample on a $1.5 \%$ agarose electrophoresis gel. A smear from approximately $200-1000$ bp should be visualized (Figure $2 \mathrm{~A}$ )

\section{Cy3 Fluorescent Dye Incorporation}

1. Optional : another sample can be labeled with the Cy5 fluorescent dye and hybridized to the same microarray.

2. To incorporate aa-dNTP, add $5 \mathrm{uL}$ of Rd B sample to $45 \mathrm{uL}$ of a master mix consisting of $5 \mathrm{uL} 10 \mathrm{X}$ PCR buffer, $1 \mathrm{uL} 12.5 \mathrm{mM}$ aadNTP(Invitrogen), $1 \mathrm{uL} 100 \mathrm{pmol} / \mathrm{uL}$ primer B, 1, $1 \mathrm{uL}$ KlenTaq LA (Sigma), and $37 \mathrm{uL}$ water. Run PCR protocol as follows: $94^{\circ} \mathrm{C}, 2 \mathrm{~min}$ $\rightarrow\left(15\right.$ cycles of $\left.94^{\circ} \mathrm{C}, 30 \mathrm{~s} / 50^{\circ} \mathrm{C}, 45 \mathrm{~s} / 72^{\circ} \mathrm{C}, 1 \mathrm{~min}\right) \rightarrow 72^{\circ} \mathrm{C}, 5 \mathrm{~min} \rightarrow 10^{\circ} \mathrm{C}$ (hold)

3. Clean the Rd C sample with the DNA Clean and Concentrator-5 Kit (Zymo Research) per the manufacturer's instructions. Elute in $10 \mu \mathrm{L}$.

4. Add $1 \mathrm{uL}$ of $1 \mathrm{M}$ bicarbonate (Sigma) and $1 \mathrm{uL}$ Cy5 (GE Healthcare) to the Rd C sample.

5. Incubate $x 1$ hour in the dark.

6. Clean the Cy3-labeled sample with the DNA Clean and Concentrator-5 Kit (Zymo Research) per the manufacturer's instructions. Elute in 12 $\mu \mathrm{L}$.

\section{Hybridization to Virochip Microarray}

1. Optional: use $1.5 \mu \mathrm{L}$ to check cDNA concentration and the amount of dye incorporated on a Nanodrop spectrophotometer (for normalization of samples)

2. In a PCR strip tube add $1 \mu \mathrm{L} 25 \mathrm{X}$ fragmentation buffer, $5 \mu \mathrm{L} 5 \mathrm{X}$ blocking buffer, $9.5 \mu \mathrm{L}$ (or amount to normalize) of Cy3-labeled sample, and water to a total volume of $25 \mu \mathrm{L}$ (Agilent)

3. Add $25 \mu \mathrm{L}$ of $2 X$ GEx hybridization buffer (Agilent). Spin down briefly to remove bubbles.

4. Load $40 \mu \mathrm{L}$ of the sample onto gasket slide.

5. Place Agilent-printed Virochip array (University of California, San Francisco / Agilent) (side marked "Agilent" down) on top of gasket slide and fasten screw tightly.

6. Hybridize overnight in $65^{\circ} \mathrm{C}$ oven, speed setting at $10 \mathrm{rpm}$.

7. To wash arrays, preheat buffer 2 (Agilent) to $37^{\circ} \mathrm{C}$. Take apart gasket slide / array sandwich underwater in buffer 1 (Agilent). Wash in buffer $1 \times 1 \mathrm{~min}$. Wash in preheated buffer $2 \times 1 \mathrm{~min}$. Slowly remove slide from buffer 2, being careful to avoid bubbles (use kimwipe to wick away extra moisture being careful to avoid directly touching active side of array)

8. Place slide into slide holder and insert into array scanner.

\section{Virochip Scanning and Analysis}

1. Scan Cy3-labeled array at $5 \mu \mathrm{m}$ or $2 \mu \mathrm{m}$ according to the instrument's standard scanning protocol (Figure 2B).

2. Analyze Virochip microarrays by visual inspection, cluster analysis, or the automated Virochip analysis program, E-Predict ${ }^{11}$. By each of these three methods, influenza virus is readily detected in the nasal swab sample (from a child with influenza-like illness) (Figure $2 \mathrm{C}$ )

\section{Representative Results:}

When the protocol is done correctly, a smear should be seen on agarose gel electrophoresis after the Rd B step (Figure 2A). The Virochip microarray on the Agilent platform will be difficult to analyze visually (Figure 2B), but if a virus is present it should be readily identified by visual inspection, cluster analysis, and / or E-Predict (Figure 1C). Samples can be spiked with measured quantities of nucleic acid from a known virus (e.g. tobacco mosaic virus; MS2 bacteriophage) to serve as a positive control for the assay. 


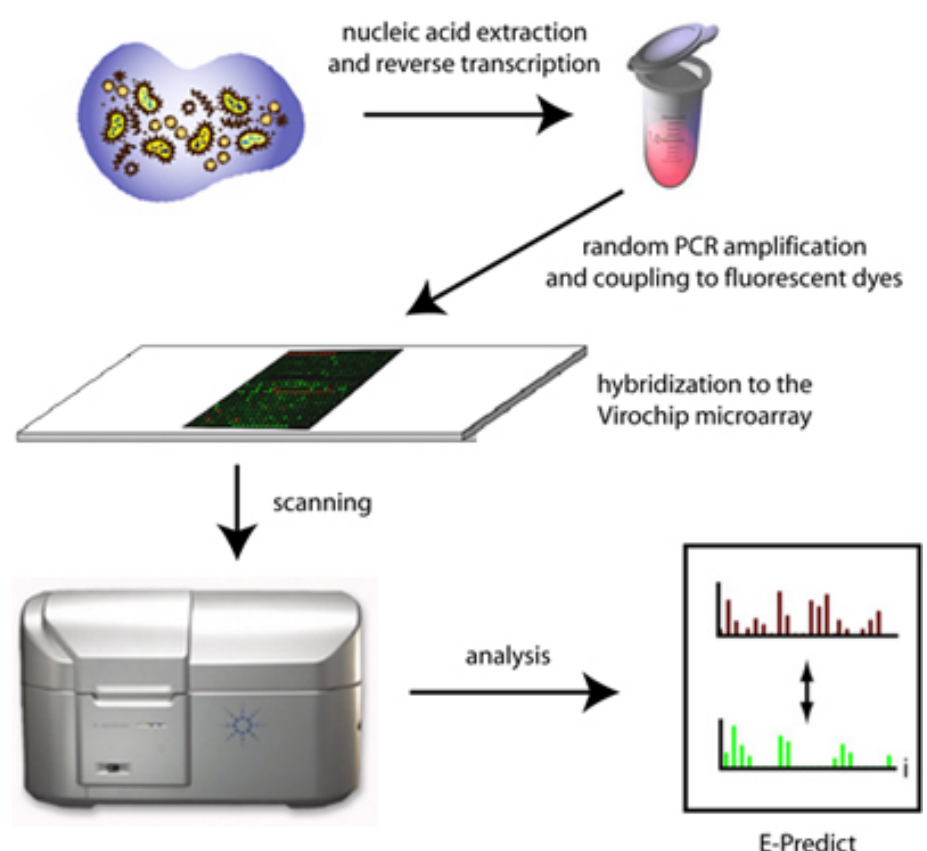

Figure 1. Schematic of Virochip microarray processing and analysis. Extracted nucleic acid from clinical samples are randomly amplified, labeled with fluorescent dyes, and hybridized to the Virochip microarray. Microarrays are scanned at $2 \mu \mathrm{m}$ resolution and analyzed using a variety of computational tools, including E-Predict.

\section{A}

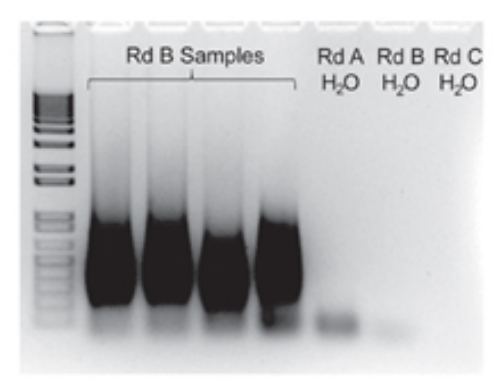

B

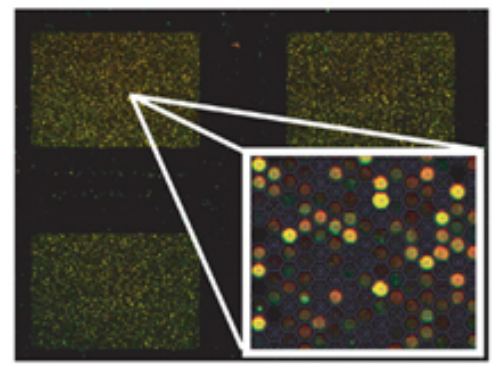

C

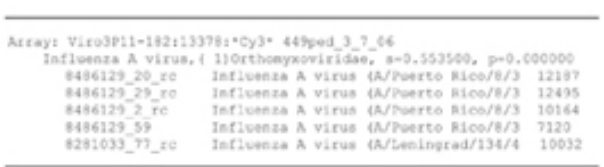

Figure 2. Steps in the Virochip assay. After amplification by random PCR, a smear of $200-1000$ bp can be visualized by gel electrophoresis (A). (B) Three Virochip microarrays out of the 8 arrays / glass slide are shown, with a small region of one microarray blown-up in the inset on the bottom right corner. (C) Automated microarray viral analysis using E-Predict revealing the presence of influenza A virus in the clinical sample. The high similarity score $(s=0.55)$ corresponds to a $p$-value that is close to zero, thus making this an extremely significant prediction. 


\section{Discussion}

The Virochip protocol as described here is complex and requires a meticulous and skilled research technician. Correct reagent concentrations and conditions for PCR, labeling, and hybridization are critical. The Virochip protocol can be easily modified to accommodate analysis of diseased tissues by use of a tissue extraction method such as TRIzol (Invitrogen) for nucleic acid extraction. Probes can be added or deleted as necessary to obtain the desired spectrum and breadth of coverage; for instance, probes for detection of nonviral targets such as bacteria and fungi can be designed and added "on-the-fly". Some applications of the Virochip assay currently under development include broad-spectrum viral diagnostics in the clinical laboratory, outbreak investigation, purity screening of drugs and vaccines, and novel viral pathogen discovery.

\section{Disclosures}

No conflicts of interest declared.

\section{Acknowledgements}

We thank David Wang, Anatoly Urisman, Amy Kistler, Kael Fischer, Patrick Tang, and Alexander Greninger for the initial development and optimization of the Virochip protocol. This work is supported by an NIH K08 grant and Abbott Discovery Award (to CC) and the Howard Hughes Medical Institute (to JLD).

\section{References}

1. Wang, D.,et al. Microarray-based detection and genotyping of viral pathogens. Proc Natl Acad Sci U S A 99, 15687-15692 (2002).

2. Chiu, C.Y.,et al. Diagnosis of a critical respiratory illness caused by human metapneumovirus by use of a pan-virus microarray. $J$ Clin Microbiol 45, 2340-2343 (2007).

3. Chiu, C.Y.,et al. Microarray detection of human parainfluenzavirus 4 infection associated with respiratory failure in an immunocompetent adult. Clin Infect Dis 43, e71-76 (2006).

4. Chiu, C.Y.,et al. Utility of DNA microarrays for detection of viruses in acute respiratory tract infections in children. J Pediatr 153, 76-83 (2008).

5. Kistler, A.,et al. Pan-viral screening of respiratory tract infections in adults with and without asthma reveals unexpected human coronavirus and human rhinovirus diversity. J Infect Dis 196, 817-825 (2007).

6. Rota, P.A.,et al. Characterization of a novel coronavirus associated with severe acute respiratory syndrome. Science 300, 1394-1399 (2003).

7. Wang, D.,et al. Viral discovery and sequence recovery using DNA microarrays. PLoS Biol 1, E2 (2003).

8. Urisman, A.,et al. Identification of a novel Gammaretrovirus in prostate tumors of patients homozygous for R462Q RNASEL variant. PLoS Pathog 2, e25 (2006).

9. Kistler, A.L.,et al. Recovery of divergent avian bornaviruses from cases of proventricular dilatation disease: identification of a candidate etiologic agent. Virol J 5, 88 (2008).

10. Chiu, C.Y.,et al. Identification of cardioviruses related to Theiler's murine encephalomyelitis virus in human infections. Proc Natl Acad Sci U $S$ A 105, 14124-14129 (2008).

11. Urisman, A.,et al. E-Predict: a computational strategy for species identification based on observed DNA microarray hybridization patterns. Genome Biol 6, R78 (2005). 